\title{
DETERMINATION OF NITRITE AND NITRATE LEVEL IN WASTEWATER DISCHARGE FROM SMOKED FISH INDUSTRY
}

\author{
Wina Yulianti ${ }^{1)}$, Ima Kusumanti ${ }^{2)^{*}}$ dan Nurul Jannah ${ }^{3)}$
}

${ }^{1}$ Program Studi Analisis Kimia, IPB, Jl. Kumbang No.14, Cilibende, Bogor 16128, Indonesia ${ }^{2}$ Program Studi Teknologi Produksi dan Manajemen Budidaya Perikanan, IPB, Jl. Kumbang No.14, Cilibende, Bogor 16128, Indonesia

${ }^{3}$ Program Studi Teknik Manajemen Lingkungan, IPB, Jl. Kumbang No.14, Cilibende, Bogor 16128, Indonesia

\section{ARTICLE INFO}

Article history:

Received 21 Jun 2021,

Revised 03 Jan 2022 ,

Accepted 16 Jan 2022

Available online 24 Jan 2022

Keywords:

$$
\begin{array}{ll}
\checkmark & \text { Alo River } \\
\checkmark & \text { nitate } \\
\checkmark & \text { nitrite } \\
\checkmark & \text { smoked fish } \\
\checkmark & \text { spectrophotometer }
\end{array}
$$

*corresponding author: wjuans@apps.ipb.ac.id Phone: +628121918444

https://doi.org/10.31938/jsn.v $\underline{12 \mathrm{i} 1.323}$

\begin{abstract}
This research aimed to determine nitrite and nitrate contamination in wastewater discharge from the smoked fish industry around the fishpond area in Penatarsewu village, Sidoarjo East Java. Samples were taken from ten locations along The Alo River from September to November 2020. Nitrate and nitrite levels were determined by the Standard Method for Examination of Water and Wastewater 4500-NO $\mathrm{N}_{2} \mathrm{~B}$ dan 4500-NO $\mathrm{O}_{3}-\mathrm{B}$. Nitrite formed a reddishpurple azo dye produced by coupling diazotized sulfanilamide with $N$-(1-naphthyl)ethylene-diamine dihydrochloride after a visible spectrophotometer measured the complexes nitrite at wavelength $543 \mathrm{~nm}$. Meanwhile, the Nitrate level was determined by ultraviolet spectrophotometer at a wavelength of $220 \mathrm{~nm}$. The standard nitrite calibration curve was shown by the line equation $y=3,30361 x-0,0028$ and a determination coefficient of 0.9999. Whereas the standard nitrate was showed by the line equation $y=0,2507 x+$ 0,0067 and a determination coefficient 0,9996. The level of nitrate and nitrite in the sample ranged from $0.05-0.93 \mathrm{mg} / \mathrm{L} 1,2-1,6 \mathrm{mg} / \mathrm{L}$. According to a quality standard threshold value for nitrite and nitrate-based on the Government Regulation of the Republic of Indonesia (PPRI) No.82 2001 is $0,06 \mathrm{mg} / \mathrm{L}$ and $10 \mathrm{mg} / \mathrm{L}$, therefore it can be concluded that some samples are above the threshold value for nitrite level
\end{abstract}

\section{ABSTRAK \\ Penentuan Kadar Nitrit dan Nitrat Pembuangan Limbah Cair Industri Ikan Asap}

Penelitian bertujuan untuk menentukan tingkat kontaminasi nitrat dan nitrit pada limbah industri ikan asap di sekitar kawasan tambak ikan asap di Desa Penatarsewu, Sidoardjo, Jawa Timur. Sampel diambil dari 10 titik di areal sekitar tambak sepanjang badan Sungai Alo pada bulan September sampai November 2020. Penentuan kadar nitrat dan nitrit mengacu pada Standard Methods for the Examination Water and Wastewater $4500-\mathrm{NO}_{2}-\mathrm{B}$ dan $4500-\mathrm{NO}_{3}$-B. Nitrit membentuk kompleks ungu kemerahan yang dihasilkan dari kopling sulfanilamida dengan $\mathrm{N}$-(1-naptil)-etilena-diamina dihidroklorida kemudian kadarnya ditentukan dengan spektrofotometer sinar tampak pada panjang gelombang 543 nm. Kadar nitrat ditentukan menggunakan spektrofotometer ultraviolet pada panjang gelombang $220 \mathrm{~nm}$. Hasil pengukuran standar nitrit menghasilkan persamaan garis $\mathrm{y}=3,30361 \mathrm{x}-0,0028$ dengan koefesien determinasi 0,999 dan standar nitrat menghasilkan persamaan garis $y=0,2507 x+0,0067$ dengan koefesien determinasi 0,9996 . Kadar nitrit dan nitrat secara berturut-turut berkisar antara $0,05-0,93 \mathrm{mg} / \mathrm{L}$ dan 1,2-1,6 mg/L. Berdasarkan nilai ambang batas baku mutu nitrit dan nitrat berdasarkan Peraturan Pemerintah Republik Indonesia (PPRI) No.82 tahun 2001 adalah $0,06 \mathrm{mg} / \mathrm{L}$ dan $10 \mathrm{mg} / \mathrm{L}$, maka dapat disimpulkan bahwa beberapa sampel mengandung kadar nitrit di atas ambang batas.

Kata kunci : ikan asap, nitrat, nitrit, Sungai Alo, spektrofotometer

\section{PENDAHULUAN}

Sektor perikanan sangat berperan penting dalam pemenuhan kebutuhan pangan di
Indonesia. Namun dalam pemenuhan kebutuhan pangan tersebut, pengolahan ikan memiliki keterbatasan dalam hal umur simpannya. Ikan merupakan zat organik yang mudah membusuk, 
dengan demikian berbagai upaya pengolahan ikan dilakukan untuk memperpanjang umur simpannya. Pengolahan ikan juga bertujuan untuk dapat meningkatkan citra rasa sehingga menghasilkan produk yang lebih menarik minat konsumen dan dapat meningkatkan nilai ekonomis.

Industri pengolahan ikan dapat dibagi menjadi proses industri pembekuan, pengasapan, penepungan, pembuatan minyak ikan dan pengalengan (Setiadi et al., 2019). Teknik pengolahan ikan yang dilakukan di desa Penatarsewu, Sidoardjo, Jawa Timur adalah pengasapan ikan. Lebih dari $90 \%$ masyarakatnya mengggantungkan kehidupannya dari pengolahan ikan asap mujair (Kusumanti et al., 2021). Teknik pengasapan ikan adalah salah satu teknik pengawetan makanan yang tertua di dunia. Tujuan utama pengasapan ikan adalah untuk mengeringkan ikan sehingga ikan sukar teroksidasi dan memperlambat proses pembusukan (Setiadi et al., 2019). Kelompok senyawa kimia dalam asap kayu yaitu karbonil (aldehida dan keton), asam organik, fenolik, basa organik, alkohol, hidrokarbon, gas $\mathrm{CO}_{2}, \mathrm{CO}, \mathrm{O}_{2}$, dan nitrogen. Beberapa senyawa asap tersebut bersifat antioksidan dan bakterisidal (Sulistijowati et al., 2011).

Proses pengasapan ikan terdiri dari tahapan pencucian, penggaraman dan pengasapan. Pada tahapan pencucian dilakukan proses pemotongan sirip, ekor, kepala, pengeluaran isi perut. Ikan kemudian dibersihkan sebelum dilakukan penggaraman. Proses penggaraman dilakukan sampai garam meresap ke dalam daging. Tahap selanjutnya adalah proses pengeringan dan pengasapan. Terdapat tiga tahap pada proses pengasapan, yaitu pengeringan, pengasapan, pemasakan awal dan pematangan ikan (Suhu 80 $\left.{ }^{\circ} \mathrm{C}\right)$ (Setiadi et al., 2019).

Permasalahan yang sering muncul dari kegiatan industri perikanan adalah kurangnya perhatian terhadap air limbah sisa pengolahan ikan. Air sisa produksi berwarna kecoklatan keruh, berbau amis dibuang ke badan sungai tanpa dilakukan pengolahan terlebih dahulu. Limbah air tersebut mengandung berbagai macam bahan organik yang tinggi, seperti sisa isi perut, sisa daging, darah, lemak, karbohidrat dan protein (Saputra et al., 2016). Tingginya bahan organik pada limbah air tersebut dapat mempengaruhi perkembangan mikroorganisme. Dengan demikian pemantauan karakteristik limbah mencakup parameter fisika dan kimia menjadi faktor yang sangat penting untuk dianalisis

Salah satu parameter kimia penentu kualitas air adalah nitrogen. Unsur nitrogen merupakan salah satu unsur yang berperan sebagai penentu produktivitas air. Produktivitas air dalam menghasilkan material organik sangat berperan dalam mempertahankan keberlangsungan biota akuatik. Produktivitas yang relatif tinggi diperlukan untuk kehidupan ikan dan berfungsi sebagai dasar rantai makanan dan ekosistem perairan. Namun produksi yang berlebihan mengakibatkan pembusukan biomassa yang dihasilkan, tingginya konsumsi oksigen terlarut akan menghasilkan aroma air yang tidak enak (Dey et al. 2021). Tingginya kadar nitrogen juga dapat menyebabkan eutrofikasi. Proses eutrofikasi dapat terjadi jika kadar nitrogen melebihi $0,20 \mathrm{mg} / \mathrm{L}$ (Huang et al., 2015).

Efek nitrat dan nitrit bagi manusia dilaporkan dapat menyebabkan methemoglobinemia (blue syndrom) (Dey et al. 2021). Nitrit dapat mengganggu sistem transformasi oksigen dalam tubuh, karena menyebabkan konversi irreversible hemoglobin menjadi methemoglobin dalam aliran darah, dimana kemampuan hemoglobin untuk menukar oksigen sangat tergangu. Efek nitrat yang lain adalah dapat menyebabkan kanker lambung yang dikaitkan dengan nitrosamine di perut yang diproduksi oleh tingginya kadar nitrat dan nitrit (Taziki et al., 2016).

Penelitian ini bertujuan untuk menentukan tingkat kontaminasi nitrat dan nitrit pada badan air sungai di desa Penatarsewu, Sidoardjo, Jawa Timur sebagai dampak dari teknik pengolahan ikan dengan metode pengasapan. Penentuan kadar nitrat dan nitrit mengacu pada Standard Methods for the Examination Water and Wastewater 4500- $\mathrm{NO}_{2}{ }^{-} \mathrm{B}$ dan $4500-\mathrm{NO}_{3}{ }^{-} \mathrm{B}$ (American Public Health Association, 2017)

\section{BAHAN DAN METODE}

\section{Bahan dan Alat}

Bahan yang digunakan meliputi bahan uji dan bahan kimia. Bahan uji adalah sampel air yang diperoleh dari limbah air di sekitar area pembuangan pengolahan ikan asap. Bahan kimia yang digunakan adalah air bebas nitrit, $\mathrm{HCl} 1 \mathrm{M}$, $\mathrm{NH}_{4} \mathrm{OH} 1 \mathrm{M}, \mathrm{NaNO}_{2}, \mathrm{CHCl}_{3}, \mathrm{KMnO}_{4} 0,05 \mathrm{~N}$, $\mathrm{H}_{2} \mathrm{SO}_{4 \mathrm{p}}, \quad \mathrm{Na}_{2} \mathrm{C}_{2} \mathrm{O}_{4} \quad 0,025 \mathrm{M}$, ferro ammonium sulfat $0,05 \mathrm{M}, \mathrm{H}_{3} \mathrm{PO}_{4} 85 \%$, sufanilamida, N-(1naptil)-etilena-diamina dihidroklorida, $\mathrm{KNO}_{3}$. 
Alat yang digunakan adalah peralatan gelas, timbangan analitik, spektrofotometer UV-VIS.

\section{Metode \\ Pengambilan Sampel}

Pengambilan sampel dilakukan pada bulan September sampai November 2020. Lokasi pengambilan sampel terdiri dari sepuluh titik yang berlokasi di sepanjang sungai Alo desa Penatarsewu, Sidoardjo, Jawa Timur (Gambar 1). Sampel yang diambil ditempatkan dalam dirigen plastik ukuran 5L.

\section{Penetuan Kadar Nitrit}

Padatan yang tersuspensi dalam sampel dihilangkan terlebih dahulu dengan menyaring sampel ke dalam saringan membran $0,45 \mu \mathrm{M}$. Sampel yang sudah disaring kemudian diatur pHnya berkisar antara 5 sampai 9 menggunakan $\mathrm{HCl} 1 \mathrm{M}$ atau $\mathrm{NH}_{4} \mathrm{OH} 1 \mathrm{M}$. $50 \mathrm{~mL}$ sampel ditambahkan dengan pereaksi pewarna dan dibiarkan stabil dengan kisaran waktu antara 1060 menit. Standar dibuat dengan konsentrasi 0; 0,$02 ; \quad 0,05 ; \quad 0,1 ; 0,3 ; \quad 0,5 \quad \mathrm{mg} / \mathrm{L}$. Standar diperlakukan sama dengan sampel. Sampel dan standar diukur serapannya menggunakan spektrofotometer pada panjang gelombang 543 nm.

\section{Penentuan Kadar Nitrat}

Sampel terlebih dahulu disaring kemudian $50 \mathrm{~mL}$ sampel ditambahkan dengan $\mathrm{HCl} 1 \mathrm{M}$ dan diaduk. Standar yang digunakan adalah standar $\mathrm{NO}_{3}-\mathrm{N}$ dengan konsentrasi antara 0,1,2,3,4,5 $\mathrm{mg} / \mathrm{L}$. Serapan sampel dan standar diukur menggunakan spektrofotometer UV pada panjang gelombang $220 \mathrm{~nm}$ dengan akuades sebagai blanko.

\section{HASIL DAN PEMBAHASAN}

Pengambilan sampel air berlokasi di daerah sekitar tambak ikan sepanjang sungai Alo desa Penatarsewu, Sidoardjo, Jawa Timur. Titik pengambilan sampel mengarah ke laut. Masyarakat di sekitaran tambak umumnya melakukan teknik pengasapan ikan untuk meningkatkan nilai tambah ikan. Hasil pengukuran $\mathrm{pH}$ menunjukkan bahwa $\mathrm{pH}$ sampel berkisar antara 7,37 sampai 7,62 (Gambar 1). Berdasarkan hasil tersebut dapat disimpulkan bahwa sampel air memiliki pH yang baik. Berdasarkan nilai ambang batas PP RI No 82 Tahun 2010, Air dapat digunakan untuk prasarana/sarana rekreasi air, pembudidayaan ikan air tawar, peternakan, air untuk mengairi pertanaman, dan atau peruntukan lain yang mempersyaratkan mutu air yang sama dengan kegunaan tersebut.

Penentuan kadar nitrat menggunakan metode spektrofotometri. Nitrit pada kondisi asam (pH antara 2 sampai 2,5) akan membentuk ungu kemerahan yang dihasilkan dari kopling sulfanilamida dengan N-(1-naptil)-etilenadiamina dihidroklorida. Kompleks yang terbentuk diukur serapannya menggunakan spektrofotometer sinar tampak pada panjang gelombang $543 \mathrm{~nm}$ (American Public Health Association, 2017).

\section{Penatarsewu Village, Sidoarjo, East Java}
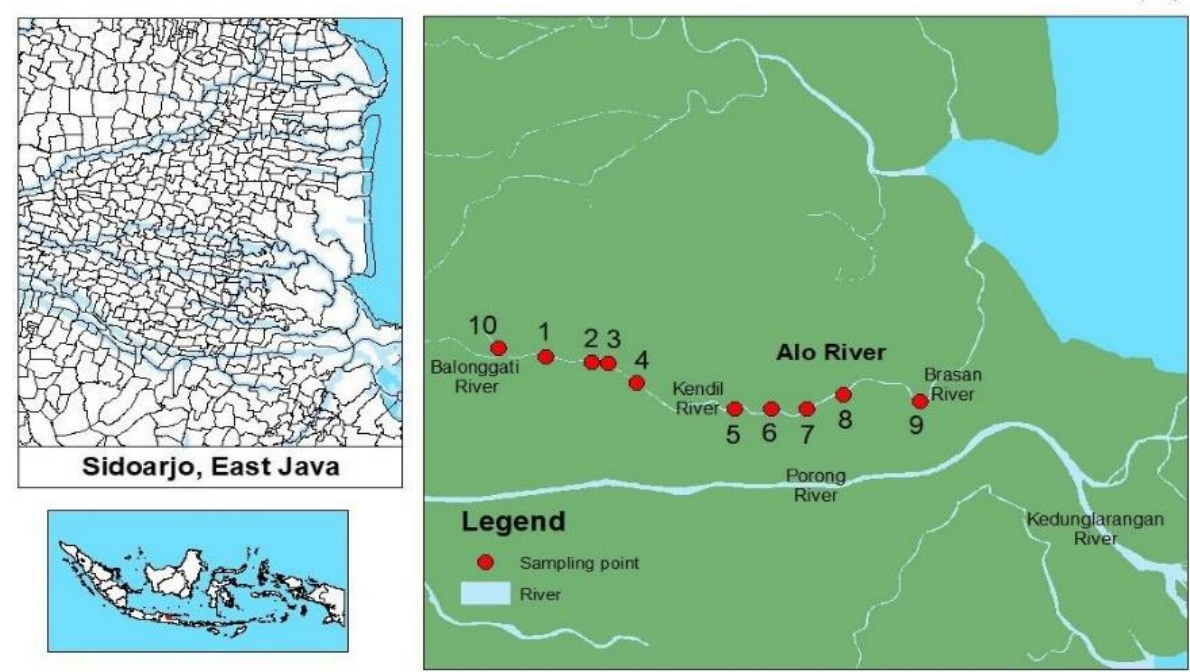

Gambar 1. Lokasi pengambilan sampel 
Standar yang digunakan pada penentuan kadar nitrat dibuat dengan konsentrasi $0 ; 0,02$; 0,$05 ; \quad 0,1 ; 0,3$ dan $0,5 \mathrm{mg} / \mathrm{L}$. Persamaan matematika yang diperoleh pada pengukuran standar adalah $\mathrm{y}=3,30361 \mathrm{x}-0,0028$ dengan koefesien determinasi 0,999. Hubungan linier yang ideal ditunjukkan dengan nilai intersep 0 dan nilai koefesien determinasi $\left(\mathrm{R}^{2}\right)+1$ atau -1 (Riyanto, 2014). Slope yang diperoleh dari persamaan adalah 3,30361 dan intersep -0,0028, Berdasarkan hasil tersebut dapat disimpulkan bahwa hubungan proposional antara hasil pengukuran dengan konsentrasi analit menunjukkan ketelitian yang tinggi dapat dilihat dari koefesien determinasi yang mendekati 1 . Nilai slope yang besar dan intersep yang mendekati nol menunjukan pengukuran memiliki sensitifitas yang tinggi (Gambar 3).

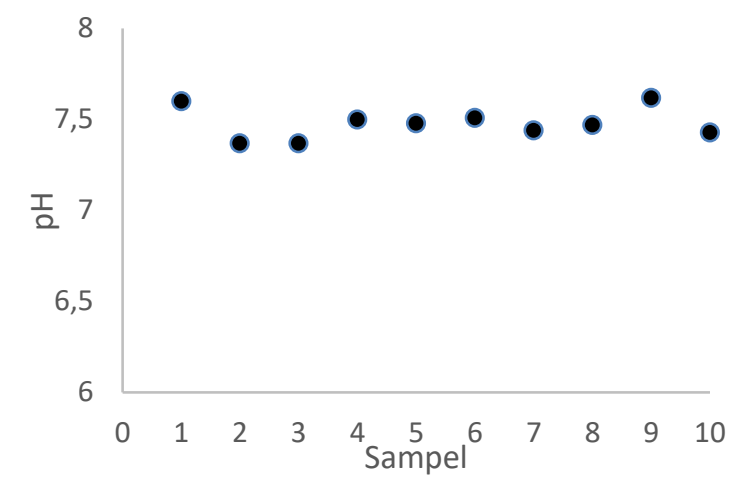

Gambar 2 Nilai pH sampel

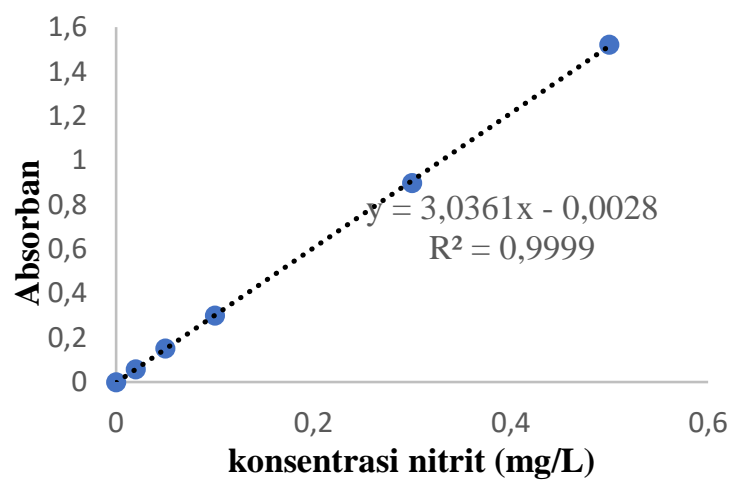

Gambar 3. Kurva kalibrasi standar nitrit

Pada penentuan nitrat, sampel tidak direaksikan dengan kompleks warna. Sampel diukur serapannya mengunakan spektrofotometer UV pada panjang gelombang $220 \mathrm{~nm}$ (American Public Health Association, 2017). Standar yang digunakan pada penentuan kadar nitrat dibuat dengan konsentrasi $0,1,2,3,4$ dan $5 \mathrm{mg} / \mathrm{L}$. Persamaan garis yang diperoleh pada pengukuran standar adalah $\mathrm{y}=0,2507 \mathrm{x}+0,0067$ dengan koefesien determinasi 0,9996. Hubungan proposional antara hasil pengukuran dengan konsentrasi analit menunjukkan ketelitian yang tinggi dapat dilihat dari koefesien determinasi yang mendekati 1 . Nilai slope yang besar dan intersep yang mendekati nol menunjukan pengukuran memiliki sensitifitas yang tinggi (Gambar 4).

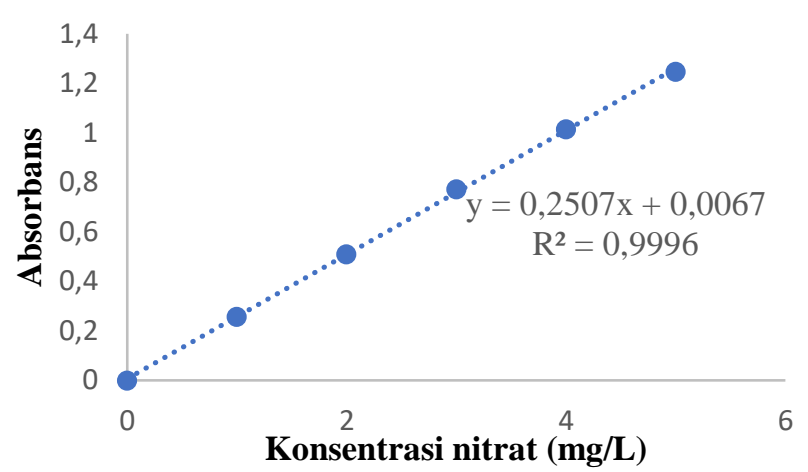

Gambar 4. Kurva kalibrasi standar nitrat

Pada pengukuran sampel air sungai menunjukkan nilai kadar nitrat lebih tinggi dibandingkan dengan kadar nitrit. Nitrit adalah senyawa intermedit antara amonium dan nitrat. Amonium teroksidasi menjadi nitrit dan kemudian nitrit teroksidasi menjadi nitrat (Manahan, 2001). Nitrit umumnya ditemukan dalam jumlah yang kecil dibandingkan nitrat. Nitrit bersifat tidak stabil dan akan mengalami oksidasi menjadi nitrat melalui proses nitrifikasi. Dengan demikian berdasarkan data yang diperoleh dapat disimpulkan bahwa nitrogen pada sampel berada pada kondisi bilangan oksidasi tertinggi. Hasil analisis juga menunjukan kecenderungan berbanding terbalik antara kadar nitrat dan nitrit. Hal ini bisa dilihat dari sampel 8 dan 9 menunjukan kadar nitrit terendah, hal ini berbanding terbalik dengan kadar nitratnya yang menunjukkan kadar nitrat yang paling tinggi (Gambar 5).

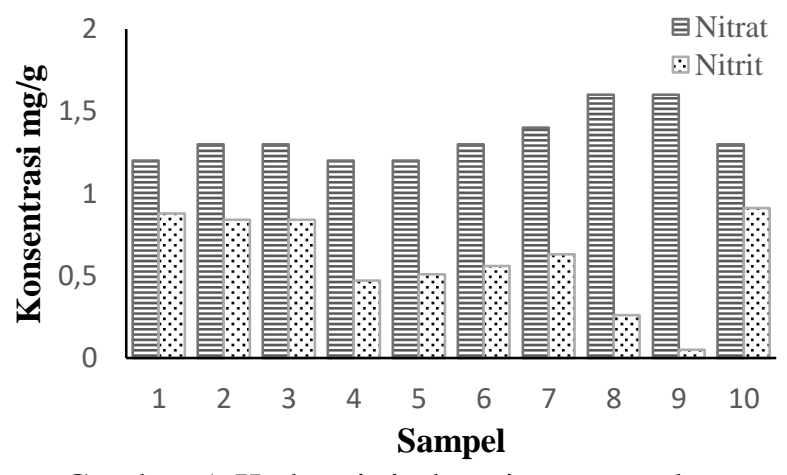

Gambar 5. Kadar nitrit dan nitrat sampel

Kadar nitrit pada sampel menunjukkan nilai yang bervariasi. Sampel 9 menunjukkan kadar terendah $0,05 \mathrm{mg} / \mathrm{L}$ dan sampel 10 menunjukkan kadar tertinggi $0,93 \mathrm{mg} / \mathrm{L}$. 
Berdasarkan Peraturan Pemerintah Republik Indonesia (PPRI) No.82 tahun 2001, batas mutu kadar nitrat di dalam air adalah 0,06 mg/L (PP RI, 2001). Berdasarkan data yang diperoleh kadar nitrat sampel berada diatas baku mutu kecuali pada sampel 9. Hasil yang diperoleh sejalan dengan penelitian yang dilaksanakan Saputra et al., (2016). Air limbah pengolahan pengasapan ikan menyebabkan kadar nitrit berada di atas baku mutu. Tingginya kadar nitrit yang berada di atas baku mutu mengindikasikan jumlah terbatasnya jumlah oksigen terlarut dalam air sehingga nitrit tidak teroksidasi sempurna menjadi nitrat. Sedangkan pada sampel 9 hampir semua nitrit teroksidasi menjadi nitrat, dengan demikian dapat diperkirakan bahwa kandungan oksigen yang terkandung pada sampel 9 lebih tinggi dibandingkan pada sampel air lainnya. Kadar Nitrat pada sampel juga menunjukkan nilai yang bervariasi, yaitu berkisar antara 1,2 sampai 1,6 mg/L. Berdasarkan Peraturan Pemerintah Republik Indonesia (PPRI) No.82 tahun 2001, batas mutu kadar nitrat di dalam air adalah 10 $\mathrm{mg} / \mathrm{L}$. Dengan demikian, kadar Nitrat sampel berada di bawah nilai ambang batas.

Tinginya kadar nitrit hampir di semua sampel mengindikasikan bahwa aktifitas pengolahan ikan asap diduga berkontribusi pada peningkatan kadar nitrit. Kadar nitrit juga dapat dipengaruhi oleh masuknya limbah dosmetik atau aktivitas pemupukan lahan pertanian, aktivitas pertenakan di sekitar area pengambilan sampel (Yogafanny, 2015). Nitrit merupakan salah satu parameter kimia untuk menentukan kualitas air. Tingginya kadar nitrit dapat menyebabkan eutrofikasi yang dapat menggangu keseimbangan ekologi perairan

\section{KESIMPULAN}

Tingkat kontaminasi nitrat dan nitrit pada badan air sungai di desa Penatarsewu, Sidoardjo, Jawa Timur menunjukkan nilai di atas baku mutu untuk nitrit dan di bawah baku mutu untuk nitrat berdasarkan Peraturan Pemerintah Republik Indonesia (PPRI) No.82 tahun 2001. Tingginya kadar nitrit hampir di semua sampel mengindikasikan bahwa aktifitas pengolahan ikan asap diduga berkontribusi pada peningkatan kadar nitrit.

\section{UCAPAN TERIMA KASIH}

Penulis mengucapkan terimakasih kepada semua pihak yang sudah membantu kegiatan penelitian. Terimakasih diucapkan kepada Sekolah Vokasi IPB yang sudah memberikan dana hibah penelitian tahun 2020, Laboratorium PT Sucofindo, Jawa Timur yang sudah berkerjasama dalam menganalisis sampel dan Mahasiswa Program Studi Teknologi Produksi dan Manajemen Perikanan yang telah membantu pada saat sampling.

\section{DAFTAR PUSTAKA}

American Public Health Association. (2017). Standard Methods. In R. Baird, A. D. Eaton., \& E. W. Rice (Eds.), Standard Methods for the Examination of Water and Wastewater (23rd ed.). American Public Health Association.

Dey S, Haripavan N, Basha SR, Babu GV. (2021). Removal of ammonia and nitrates from contaminated water by using solid waste bio-adsorbents. Current Research in Chemical Biologi. 2021.100005

Huang, J., Yang, P., Li, C., Guo, Y., Lai, B., Wang, Y., Feng, L., \& Zhang, Y. (2015). Effect of Nitrite and Nitrate Concentrations on the Performance of AFB-MFC Enriched with High-Strength Synthetic Wastewater. Biotechnology Research International, 2015, 1-6.

Kusumanti, I., Yulianti, W., \& Jannah, N. (2021). Physiochemical property of wastewater discharged from smoked fish industry around fishponds area in Penatarsewu Village, Sidoardjo, East Java. IOP Conference Series: Earth and Environmental Science, 744(1), 012037.

Manahan, S. E. (2001). Environmental chemistry. In Energy (8th ed.). CRC Press.

PP RI. (2001). Peraturan Pemerintah Republik Indonesia Nomor 82 Tahun 2001 tentang Pengelolaan Kualitas Air dan Pengendalian Pencemaran Air. Peraturan Pemerintah Republik Indonesia, 1-41.

Riyanto, P. D. (2014). Validasi \& Verifikasi Metode Uji Sesuai dengan ISO/IEC 17025 Laboratorium Pengujian dan Kalibrasi. 


\section{DEEPUBLISH.}

Saputra, A. dony, Haerudin, \& Widyorini, N. (2016). Efektivitas Kombinasi Mikroorganisme Dan Tumbuhan Air Lemna Minor Sebagai Bioremediator Dalam Mereduksi Senyawa Amoniak, Nitrit, Dan Nitrat Pada Limbah Pencucian Ikan. Management of Aquatic Resources, 5, 8090.

Setiadi, T., Ismail, G. A., \& Watari, T. (2019). Pedoman Pengolahan Air Limbah Industri Pengolahan Ikan di Indonesia Pedoman Pengolahan Air Limbah Industri Pengolahan Ikan di Indonesia Bulan Maret , 2019 Kerjasama teknis co-benefits approach KLHK Indonesia dan KLH Jepang. August 2020.
Sulistijowati, rieny S., Suhara, otong D., Nurhajati, J., Afrianto, E., \& Udin, Z. (2011). Mekanisme Pengasapan Ikan. 6592.

http://repository.ung.ac.id/karyailmiah/sho w/240/mekanisme-pengasapan-ikan.html

Taziki, M., Ahmadzadeh, H., \& A. Murry, M. (2016). Growth of Chlorella vulgaris in High Concentrations of Nitrate and Nitrite for Wastewater Treatment. Current Biotechnology, 4(4), 441-447.

Yogafanny, E. (2015). Pengaruh Aktifitas Warga di Sempadan Sungai terhadap Kualitas Air Sungai Winongo. Jurnal Sains \&Teknologi Lingkungan, 7(1), 29-40. 